\title{
Implementasi Startegi Penanaman Pendidikan Nilai untuk Membentuk Karakter Disiplin Siswa SDN Batu Belah Timur I Kecamatan Dasuk
}

\author{
Syaiful Bahri \\ STKIP PGRI Sumenep \\ syaifulbahri@stkippgrisumenep.ac.id
}

\begin{abstract}
Abstrak
Penelitian ini dilatar belakangi oleh banyaknya pelanggaran nilai dikalangan remaja dan anak usia sekolah. Siswa SD dijaman sekarang sudah banyak sekali yang tidak memperdulikan nilai-nilai yang berlaku di lingkungan sekolah maupun masyarakat, akibatnya banyak siswa SD yang melanggar peraturan kedisiplinan sekolah. Penelitian ini bertujuan untuk mendeskripsikan implementasi dan hasil penerapan strategi penanaman pendidikan nilai untuk meningkatkan karakter disiplin siswa SD Negeri Batu Belah Timur I Kecamatan Dasuk. Hasil penelitian ini menunjukkan ada dua strategi pengintegrasian yang dilakukan Negeri Batu Belah Timur I dalam penerapan pendidikan nilai, yaitu strategi pengintegrasian dalam kegiatan sehari-hari (keteladanan, kegiatan spontan, teguran, pengkondisian lingkungan, dan kegiatan rutin) dan strategi pengintegrasian dalam kegiatan yang diprogramkan, seperti taat pada ajaran agama diintegrasikan pada peringatan hari-hari besar keagamaan. Dengan dua strategi tersebut setidaknya mengurangi jumlah siswa yang melanggar peraturan kedisiplinan di lingkungan sekolah. Hasil penelitian menunjukkan bahwa tingkat keberhasilan pendidikan nilai di SDN Batu Belah Timur I masih $60 \%$, hal ini ditunjukkan dengan masih banyaknya siswa yang setiap harinya melanggar peraturan kedisiplian sekolah.
\end{abstract}

Kata Kunci : Strategi penanaman pendidikan nilai, peraturan sekolah

\section{PENDAHULUAN}

Pendidikan merupakan suatu sendi kehidupan. Melalui pendidikan, kecerdasan dan keterampilan manusia lebih terasah dan teruji dalam menghadapi dinamika kehidupan yang semakin kompleks. Undang-Undang Nomor 22 Tahun 2003 yanng menyatakan bahwa sekolah berusaha untuk menerapkan tata tertib sekolah dalam upaya membentuk watak serta peradaban bangsa yang bermartabat serta mencetak generasi-generasi penerus bangsa sesuai dengan kepribadian manusia Indonesia yang berlandaskan Pancasila dan Undang Undang Dasar 1945.
Pendidikan sebagai suatu upaya sadar mengembangkan potensi peserta didik (siswa), tidak dapat dilepaskan dari lingkungan mereka berada, utamanya lingkungan budaya, karena pendidikan yang tidak dilandasi prinsip budaya menyebabkan peserta didik tercabut dari akar budayanya, dan ketikahal itu terjadi maka mereka tidak akan mengenal budayanya dan akan menjadi asing dalam lingkungan budaya (masyarakat) nya, kondisi demikian menjadikan siswa cepat terpangaruh oleh budaya luar. Kecenderungan itu terjadi karena ia tidak memiliki norma dan nilai budaya yang dapat digunakan untuk melkukan 
pertimbangan (valueing). (Kemendiknas, 2010).

Pendidikan nilai dalam konteks kekinian sangat relevan dan penting untuk mengantasi krisis moral yang terjadi di Indonesia. Diakui atau tidak saat ini terjadi krisis nyata dan mengkhawatirkan karena telah berimbas kepada anak-anak dan remaja usia sekolah. Krisis tersebut berupa tawuran antar pelajar, menurunnya kejujuran, kehilangan daya kreatif (kreatifitas), tanggungjawab, dan sebagainya yang sudah menjadi masalah sosial dan ikut memberi andil terjadinya konflik ditingkat rakyat bawah (akar rumput).

Dalam kaitan tersebut, pendidikan nilai sangatlah penting. Karena melalui kegiatan tersebut nilai-nilai kebangsaan akan tersosialisasi sistimatis dan diterima semua kalangan utamanya peserta didik (siswa) sebagai generasi muda bangsa; pendidikan karakter sebagai wujud implementasi sosialisasi nilai-nilai luhur budaya bangsa, adalah format penguatan yang sistematis dan terencana. Semakin kuat seseorang memiliki dasar pertimbangan nilai kebangsaan, semakin kuat pula kecenderungan untuk tumbuh dan berkembang menjadi warga masyarakat yang baik, dan pada titik kulminasinya secara individual maupun kolektif akan memegang teguh nilai budaya.

Maksudin (2013), nilai adalah kualifikasi harga atau isi pesan yang dibawakan baik tersurat maupun tersirat dalam norma tersebut. Di antaranya, norma agama memuat nilai haram, halal, dosa, wajib, sunnat, makruh dan sebagainya. Nilai-nilai tersebut melekat pada seluruh instrumental input manusia baik materiel atau imateriel, personal atau impersonal, kondisional, maupun behavioral. Moral atau moralitas adalah tuntutan sikap- perilaku yang diminta oleh norma dan nilai tersebut. Oleh karena itu, suatu norma dari suatu sumber bisa membuat nialai moral positif maupun negatif.

Pendidikan nilai di Indonesia saat ini belum efektif dan belum mendorong pembangunan karakter bangsa, karena ukuran-ukuran dalam pendidikan tidak dikembalikan pada karakter bangsa, tetapi diarahkan pada pasar. Padahal, karakter bangsa merupakan aspek penting dari kualitas sumber daya manusia karena karakter bangsa dapat menentukan kemajuan suatu bangsa dan negaranya. Pendidikan merupakan salah satu tolak ukur tingkat kemajuan suatu bangsa dan negaranya, selain itu pendidikan juga merupakan unsur penting dalam meningkatkan harkat dan martabat serta kualitas hidup suatu bangsa. Namun dampak globalisasi membawa masyarakat Indonesia melupakan pentingnya pendidikan nilai. Padahal, pendidikan nilai merupakan salah satu pondasi bangsa yang sangat penting dan perlu ditanamkan sejak dini pada anak-anak.

Dengan adanya pendidikan nilai diharapkan siswa Sekolah Dasar (SD) dapat menjadi pribadi yang menjunjung tinggi nilai-nilai sosial yang berlaku di sekolah maupun di masyarakat. Sekolah Dasar (SD) merupakan jenjang pendidikan dasar yang diharapkan dapat menjadi fondasi pendidikan berkarakter yang kuat. Siswa Sekolah Dasar (SD) berkarakter sangat diharapkan menjadi penerus bangsa yang mampu menghadapi pasar global. Namun pada kenyataan di lapangan Sekolah Dasar (SD) yang menerapkan pendidikan nilai dan menanamkan pembelajaran berkarakter hanya sebagian kecil saja. Banyak Sekolah Dasar (SD) yang tidak memperdulikan apa tujuan pendidikan nilai, sehingga pendidikan nilai kurang maksimal penerapannya di sekolah- 
sekolah pedesaan. Siswa Sekolah Dasar (SD) berada ditahap operasional konkret, dimana pada tahap tersebut siswa akan menirukan perilaku yang dilihat setiap hari. Dalam hal ini, guru Sekolah Dasar (SD) dituntut menjadi guru yang berkarakter dalam lingkungan sekolah maupun masyarakat, yang terpenting penanaman nilai pada siswa harus dilakukan sejak usia dini.

Perlunya penanaman nilai sejak dini pada anak-anak karena jaman sekarang sudah banyak sekali siswa Sekolah Dasar (SD) yang setiap harinya melanggar peraturan sekolah bahkan melanggar nilainilai sosial masyarakat, seperti tawuran antar pelajar, tidak mematuhi rambu-rambu lalu lintas dijalan, bahkan pencurian. Siswa Sekolah Dasar (SD) yang melanggar peraturan disekolahnya bukan semertamerta karena kurang perhatian dari pihak keluarga. Tetapi, kurang tegasnya penanaman pendidikan nilai disekolah tersebut. Melihat hal itu, pemerintah Indonesia gencar memberlakukan program pendidikan berkarakter yang didalamnya terprogram pendidikan nilai yang sangat diharapkan menjadi kunci perubahan perilaku dan karakter calon penerus bangsa. Namun, kenyataan dilapangan penanaman pendidikan nilai masih kurang efektif dalam pelaksanaannya. Banyak sekolahsekolah yang dalam penanaman pendidikan nilai hanya sebagai hiasan semata.

Elmubarok (2008) pendidikan nilai secara singkat diartikan sebagai suatu proses dimana seseorang menemukan maknanya sebagai pribadi pada saat dimana nilai-nilai tertentu memberikan arti pada jalan hidupnya. Proses pengembangan nilai-nilai yang menjadi landasan dari karakter itu menghendaki suatu proses yang berkelanjutan, dilakukan melalui berbagai mata pelajaran yang ada dalam kurikulum. Dalam mengembangkan pendidikan karakter bangsa, kesadaran akan siapa dirinya dan bangsanya adalah bagian yang teramat penting, kesadaan tersebut hanya dapat terbangun dengan baik melalui pencerahan masa lalu, masa kini dan akan datang tentang bangsanya. (Kemendiknas, 2010). Pendidikan karakter sejatinya merupakan bagian esensial tugas sekolah dalam hal ini sebagai proses pembudayaan dan pemberdayaan nilai-nilai luhur dalam lingkungan satuan pendidikan (sekolah), lingkungan keluarga, dan lingkungan masyarakat. Salah satu contohnya adalah membudayakan kedisiplinan.

Disiplin sekolah menurut Foerster (Koesoema, 2010) adalah "ukuran bagi tinndakan-tindakan yang menjamin kondisi-kondisi moral yang diperlukan, sehingga proses pendidikan berjalan lancar dan tidak terganggu". Anak didik sebagai generasi penerus bangsa, sejak dini harus dikenalkan dengan nilai-nilai yang mengatur kehidupan manusia, yang berguna bagi dirinya masing-masing agar berlangsung tertib, efektif dan efisien. Norma-norma itu sebagai ketentuan tata tertib hidup harus dipatuhi atau ditaatinya. Pelanggaran atau penyimpangan dari tata tertib itu akan merugikan dirinya sendiri dan bahkan dapat ditindak dengan mendapatkan sanksi atau hukuman. Dengan kata lain setiap anak didik harus dibantu hidupsecara berdisiplin, dalam arti mau dan mampu mematuhi atau mentaati ketentuan-ketentuan yang berlaku di lingkungan keluarga, masyarakat, bangsa dan negaranya.

Ketaatan dan kepatuhan dalam menjalankan tata tertib kehidupan, tidak akan dirasakan memberatkan jika dilaksanakan dengan kesadaran akan pentingnya manfaatnya. Kemauan dan kesediaan mematuhi disiplin itu datang dari dalam diri orang yang bersangkutan atau 
tanpa paksaan dari luar atau orang lain, khususnya diri anak didiknya. Akan tetapi dalam keadaan seseorang belum memiliki kesadaran untuk mematuhi tata tertib, yang sering dirasakanya memberatkan atau tidak mengetahui manfaat dan kegunaannya, maka diperlukan tindakan memaksakan dari luar atau orang yang bertanggung jawab dalam melaksanakan dan mewujudkan sikap disiplin. Kondisi seperti itu sering ditemui pada kehidupan anak atau remaja, yang mengharuskan pendidiknya melakukan pengawasan agar tata tertib di sekolah dilaksanakan, yang sering kali juga mengharuskan untuk memberikan sanksi atau hukuman karena pelanggaran yang dilakukan oleh anak didiknya.

Sekolah merupakan wadah utama dalam membentuk karakter disiplin siswa sebagai generasi penerus bangsa. Hendaknya sekolah menjadi wadah yang baik bagi perkembangan moral dan mental peserta didik disamping peran sekolah sebagai tempat pengembangan kompetensi, bakat dan minat. Selaian iti, agar sekolah menjadi tempat sosial yang baik, dimana pertumbuhan sosial siswa dan segala aspek kepribadian siswa dapat berlangsung dengan baik.

.Upaya peningkatan disiplin disekolah perlu dilakukan. Karena pemberlakuan disiplin siswa Sekolah Dasar Negeri Batu Bwlah Timur I belum berjalan sesuai harapan sehingga perlu dilakukan strategi - strategi sebagai upaya atau cara untuk meningkatkan kedisiplinan siswa melalui pendidikan nilai yang ditanamkan pada diri siswa. Sehingga, dari berbagai permasalahan itu penulis bermaksud melakukan penelitian dengan judul "Strategi Penanaman Pendidikan Nilai Untuk Meningkatkan Karakter Disiplin Siswa SDN Batu Belah Timur I Kecamatan Dasuk “

\section{METODE}

Penelitian ini menggunakan pendekatan kualitatif karena data yang disajikan berupa kata-kata. Selanjutnya, apabila dilihat dari permasalahan yang diteliti maka penelitian ini merupakan penelitian deskriptif. Penelitian deskriptif merupakan penelitian pengumpulan data untuk mengetes pertanyaan penelitian atau hipotesis yang berkaitan dengan keadaan dan kejadian sekarang, melaporkan keadaan objek atau subjek yang teliti sesuai dengan apa adanya (Sukardi, 2003).

Penelitian ini untuk mendeskripsikan suatu keadaan, melukiskan dan menggambarkan Strategi Peningkatan Karakter Disiplin yang dilaksanakan pada SD Negeri Batu Belah Timur I. Penelitian ini menggunakan pendekatan kualitatif yang disajikan secara deskriptif. Oleh karena itu, penelitian ini merupakan penelitian deskriptif kualitatif.

Sumber data pada penelitian ini adalah data primer dan data sekunder. Dalam penelitian ini, data primer didapatkan dari wawancara dan observasi dengan Kepala Sekolah, dan 6 orang guru yang berstatus pegawai negeri sipil di SD Negeri Batu Belah Timur I. Sedangkan Data sekunder pada penelitian ini terdiri dari data dari SD Negeri Batu Belah Timur I dan informasi pendukung, yang diperoleh dari kepustakaan dan berbagai sumber.

Teknik pengumpulan data yang dilakukan dengan cara wawancara, observasi dan dokumentasi. Peneliti menggunakan kepala sekolah sebagai informan utama dan akan bertambah melibatkan guru kelas, dan siswa yang berada di SD Negeri Batu Belah Timur I. Peneliti memilih informan berdasarkan dengan kebutuhan dan terpenuhinya informasi mengenai pelaksanaan Strategi Penguatan karakter disiplin siswa di SD 
Negeri Batu Belah Timur I, yaitu orangorang yang memiliki peran penting dalam permasalahan yang ingin diketahui untuk menjawab pertanyaan penelitian. Peneliti menggunakan observasi nonpartisipan dalam pelaksanaan pengumpulan data, yaitu peniliti tidak terlibat dengan aktifitas yang diamati dan hanya sebagai pengamat independen. Sementara dalam segi instrumen peneliti menggunakan observasi terstruktur yaitu observasi yang dirancang secara sistematis tentang apa yang akan diamati, kapan dan dimana tempatnya. Sedangkan Penelitian ini menggunakan dokumen laporan, foto, internet, dan dokumen-dokumen yang ada di sekolah seperti: jadwal, tata tertib dan lain sebagainya.

Tahapan Tahapan dalam analisis data tersebut meliputi reduksi data, penyajian data, penarikan kesimpulan atau verivikasi data.

Reduksi data berarti merangkum, memili hal-hal pokok dan memfokuskan pada hal-hal yang penting, dicari tema dan polanya. Data yang diperoleh di dalam lapangan di tulis dalam bentuk uraian atau laporan yang terperinci. Data yang telah di reduksi akan memberikan gambaran yang lebih jelas. Dalam mereduksi data, setiap peliti akan di pandu oleh tujuan yang akan dicapai. Tujuan utama dalam penelitian kualitatif adalah pada temuan.

Penyajian data dilakukan dalam bentuk uraian, singakat, bagan, hubungan antar katagori, flowchart, dan sejenisnya. Miles dan Huberman (dalam Sugiyono, 2014: 341) menyatakan bahwa yang paling sering digunakan untuk menyajikan data dalam penelitian kualitatif adalah teks yang bersifat naratif.

Langkah ke tiga dalam analisis kulitatif menurut Miles dan Huberman adalah penarikan kesimpulan dan verifikasi. Kesimpulan awal yang di kemukakan masih bersifat sementara, dan akan berubah apabila tidak ditemukan bukti-bukti yang kuat yang mendukung pada tahap pengumpulan data berikutnya.

\section{HASIL DAN PEMBAHASAN}

\section{Implementasi strategi penanaman pendidikan nilai}

Untuk membentuk peserta didik yang memilki karakter disiplin, maka perlu adanya dukungan yang kuat dari pihak sekolah dan pihak orang tua siswa. Pihak sekolah berperan penting membimbing siswa saat jam sekolah, sedangkan pihak orang tua membimbing si anak diluar jam sekolah. Kedua pihak tersebut haruslah saling mendukung guna tercapainya suatu harapan dari pendidikan nilai yang diterapkan SDN Batu Belah Timur I Kecamatan Dasuk Kabupaten Sumenep.

SDN Batu Belah Timur I

Kecamatan Dasuk Kabupaten Sumenep merupakan sekolah yang mengupayakan peran serta orang tua siswa dalam mendukung program pendidikan nilai, tetapi karena kondisi lingkungan sosial yang tidak mendukung dan faktor ekonomi yang juga kurang mendukung, proses implementasi pendidikan nilai di SDN Batu Belah Timur I kurang mendapat dukungan dari orang tua siswa. Meskipun demikian SDN Batu Belah Timur I tetap menerapkan pendidikan nilai semaksimal mungkin dengan berbagai cara atau strategi khusus.

Hasil penelitian yang dilakukan menunjukkan bahwa ada dua strategi pengintegrasian yang dilakukan SDN Batu Belah Timur I dalam penerapan pendidikan nilai, yaitu strategi pengintegrasian dalam kegiatan sehari-hari dan strategi pengintegrasian dalam kegiatan yang diprogramkan, diantaranya:

a. Pengintegrasian dalam kegiatan seharihari

Pelaksanaan strategi ini dapat dilakukan melalui cara berikut: 
1) Keteladanan/contoh

Kegiatan pemberian contoh/ teladan ini bisa dilakukan pengawas, kepala sekolah, staf administrasi di sekolah yang dijadikan model bagi peserta didik. Pembiasaan keteladanan dalam bentuk sehari-hari misalnya, berpakaian rapi, berbahasa yang baik, rajin membaca, memuji kebaikan dan keberhasilan orang lain, dan datang tepat waktu. Dengan harapan peserta didik dapat mencontoh perilaku baik tersebut.

2) Kegiatan spontan

Kegiatan spontan adalah kegiatan yang dilaksanakan secara spontan pada saat itu juga misalnya, seorang guru melihat siswanya mencorat coret dinding dan langsung menegurnya, memberi senyum pada sesama, salam, sapa, dan saling mengingatkan ketika ada yang melanggar tata tertib sekolah. Kegiatan spontan ini memerlukan kesadaran dari diri sendiri seorang guru ataupun siswa.

3) Teguran

Guru perlu menegur siswa yang melakukan perilaku buruk dan mengingatkannya agar mengamalkan nilai-nilai yang baik sehingga guru dapat membantu mengubah tingkah laku mereka. Tetapi sebelum menegur dan memperingati siswa untuk berperilaku baik, seorang guru harus sudah terlebih dahulu berperilaku baik $d$ lingkungan sekolah maupun di luar lingkungan sekolah.

4) Pengkondisian lingkungan

$\begin{array}{cr}\text { Suasana } & \text { sekolah } \\ \text { dikondisikan sedemikian rupa }\end{array}$

dengan penyediaan sarana fisik misalnya,penyediaan tempat sampah, jam dinding, slogan-slogan penanaman nilai yang mudah dibaca oleh siswa, aturan/tata tertib sekolah yang ditempelkan pada tempat yang strategis sehingga setiap siswa mudah membacanya. Pengkondisian lingkungan ini sangatlah penting, karena ketika lingkungan tidak mendukung untuk siswa berperilaku baik maka siswa akan mengikuti kebiasaan buruknya tanpa memiliki rasa takut untuk berperilaku buruk.

5) Kegiatan rutin

Kegiatan rutin merupakan kegiatan yang dilakukan peserta didik secara terus-menerus dan konsisten setiap saat misalnya, berbaris sebelus masuk kelas, berdo'a sebelum dan sesudah pelajaran, senam, upacara bendera, mengucapkan salam ketiga bertemu orang lain, membersihkan kelas. Kegiatan rutin ini diharapkan dapat mengubah tingkah laku siswa menjadi lebih baik dari sebelumnya dan melatih kedisiplinan siswa.

b. Pengintegrasian dalam kegiatan yang diprogramkan

Strategi ini dilaksanakan setelah terlebih dahulu guru dan kepala sekolah membuat perencanaan nilai-nilai yang akan diintegrasikan dalam kegiatan tertentu misalnya, nilai taat beragama akan dintegrasikan pada peringatan hari-hari besar keagamaan seperti maulid nabi dan isra mi'raj, nilai toleransi diintegrasikan pada saat pembelajaran menggunakan metode diskusi kelompok, dan nilai kedisiplinan yang diintegrasikan 
pada saat upacara bendera, kegiatan olah raga dan menyeselesaikan tugas yang diberikan guru tepat waktu.

Implementasi pendidikan nilai di SDN Batu Belah Timur I berjalan dengan cukup baik dan banyak siswa yang setidaknya tidak melanggar sepenuhnya peraturan tentang kedisiplinan sekolah. Tetapi masih banyak juga siswa yang melanggar kedisiplinan sekolah setiap harinya misalnya, masih banyak siswa yang telat datang ke sekolah, pada saat upacara bendera dan upacara pramuka masih banyak siswa yang tidak menggunakan atribut lengkap, berbicara dengan temannya ketika upacara berlangsung.

Salah satu faktor yang menyebabkan kurang maksimalnya implementasi strategi pendidikan nilai SDN Batu Belah Timur I adalah kurangya dukungan dari pihak orang tua siswa. Kebanyakan orang tua siswa setiap pagi buta sudah berangkat ke ladang / sawah dan pulangnya sore. Siswa kurang mendapatkan perhatian untuk belajar dan berperilaku baik sesuai dengan usianya. Sebagian besar orang tua beranggappan bahwa yang penting sudah menyekolahkan anaknya, tanpa memikirkan lagi bimbingan apa yang akan diberikan ketika anak tersebut masuk ke sekolah.

\section{Hasil Implementasi Strategi} Pendidikan Nilai Untuk Meingkatkan Karakter Disiplin

Implementasi pendidikan nilai di SDN Batu Belah Timur I selama beberapa tahun sedikit membuahkan hasil. Sekarang ini sudah sebagian siswa SDN Batu Belah Timur I bisa mematuhi peraturan sekolah. Meskipun masih banyak siswa yang melanggar peraturan sekolah. Tetapi SDN Batu Belah Timur I setiap harinya terus dan terus memperbaiki proses implementasi pendidikan nilai. Pihak sekolah sekarang ini terus memperbaiki kekurangan yang ditimbulkan dari pihak sekolah.

Hasil wawancara dengan $M$. Zaini, M.Pd (kepala sekolah SDN Batu Belah Timur I) terkait dengan hasil penerapan pendidikan nilai di SDN Batu Belah Timur I menyatakan bahwa:

"Hasil penanaman pendidikan nilai di sekolah ini sudah cukup baik,tetapi memang masih ada sedikit kendala dalam proses pelakasanaannya yang berpengaruh juga pada hasilnya. Sebagian pihak sekolah dan juga siswa sudah bisa mematuhi peraturan sekolah dan berperilaku sesuai dengan nilai dan norma yang berlaku di lingkungan sekolah, meskipun disini peraturan sekolah tidak diterapkan secara tertulis,namun setiap harinya pihak sekolah selalu memberikan nasehat tentang mana perilaku yang baik dan kurang baik. SDN Batu Belah Timur I kedepannya akan terus memperbaiki proses penanaman pendidikan nilai di sekolah ini guna hasil yang kami harapkan dapat tercapai. Kami mengharapkan semua pihak sekolah dan juga siswa dapat patuh terhadap peraturan sekolah dan juga terbiasa berperilaku baik setiap harinya tanpa harus diingatkan setiap saat" (wawancara tanggal 10 september 2017).

Hasil penelitian menunjukkan bahwa tingkat keberhasilan pendidikan nilai di SDN Batu Belah Timur I 
memang masih 60\%, hal ini ditunjukkan dengan masih banyaknya siswa yang setiap harinya melanggar peraturan kedisiplinan sekolah. Peneliti melihat setiap hari senin pagi dilangsungkan upacara bendera dan masih banyak siswa yang datangnya terlambat serta datang dengan atribut yang tidak lengkap. Setiap hari selasa sampai jum'at pagi harinya siswa diwajibkan mengikuti senam dan lagilagi masih banyak siswa yang datang terlambat. Dan peneliti masih menjumpai siswa yang tidak menggunakan sepatu ke sekolah, mereka memakai sendal dan ketika masuk ke dalam kelas, sendal di lepas di depan pintu.

$$
\text { Kurang maksimalnya }
$$

keberhasilan pendidikan nilai untuk mematuhi peraturan sekolah di SDN Batu Belah Timur I juga dipengaruhi oleh ketetapan sekolah yang tidak membuat peraturan sekolah secara tertulis. Peraturan sekolah seperti masuk kelas pukul 06:30 dan berpakaian lengkap pada saat upacara bendera, hanya diberitahukan oleh guru dan kepala sekolah kepada siswa setiap upacara bendera. Siswa cepat lupa dan terkadang tidak menghiraukan himbauan guru dan kepala sekolah.

Pada saat siswa melanggar kedisiplinan sekolah, sanksi yang diberikan pihak sekolah kurang tegas, misalnya saat siswa tidak menggunakan sepatu ke sekolah siswa hanya ditegur dan tidak disuruh pulang untuk mengganti sendal ke sepatu. Pada saat siswa merasa bosan untuk masuk sekolah siswa tidak masuk sekolah tanpa memberikan keterangan pada pihak sekolah, tetapi pada saat jam istirahat siswa yang tidak masuk sekolah berada di halaman sekolah bermain dengan teman sebayanya. Hal itu hanya ditegur oleh pihak sekolah tanpa diberikan hukuman yang bisa membuat siswa jerah untuk melakukan hal itu lagi.

\section{SIMPULAN}

Implementasi pendidikan nilai dalam meningkatkan karakter disiplin siswa di SDN Batu Belah Timur I Kecamatan Dasuk yaitu strategi pengintegrasian dalam kegiatan sehari-hari dan strategi pengintegrasian dalam kegiatan yang diprogramkan,

Hasil penerapan pendidikan nilai untuk meningkatkan karatker disiplin di SD Negeri Batu Belah Timur I sudah cukup baik, sebagian siswa sudah dapat meningkatkan kedisplinan dengan cara mematuhi peraturan sekolah dan siswa dapat bertingkah laku cukup baik di lingkungan sekolah sesuai dengan nilainilai kebaikan seperti nilai spiritual, nilai subyektif dan nilai rasional.

\section{DAFTAR PUSTAKA}

A.Doni Koesoema. (2010). Pendidikan Karakter Strategi Mendidik anak di Zaman Global. Jakarta: Grasindo

Achmad Sanusi. (2015). Sistem Nilai. Bandung: Penerbit Nuansa Cendekia

Bestari dan Sumiati. (2008). Menjadi Warga Negara yang Baik. Jakarta: PT. Pribumi Mekar

Furchan. (2004). Pengantar Penelitian Dalam Pendidikan. Yogyakarta: Pustaka Pelajar Offset

Hamid Darmadi. (2009). Dasar Konsep Pendidikan Moral. Bandung: Alfabeta

Ichas Hamid Al-Lamri. (2005). Pengembangan Pendidikan Nilai Dalam Pembelajaran Pengetahuan Sosial Di Sekolah Dasar. Jakarta: Departemen Pendidikan Nasional 
Direktorat Jenderal Pendidikan

Tinggi

Kabul Budiyono. (2007). Nilai-nilai

Kepribadian dan Kejuangan

Bangsa Indonesia. Bandung:

Alfabeta

Kementrian Pendidikan Nasional badan

Penelitian dan Pengembangan Pusat

Kurikulum. 2010. Bahan Pelatihan:

Pengambangan

Pendidikan

Budayadan Karakter Bangsa.

Jakarta: Kemendiknas.

Lickona, Thomas. (2012). Mendidik Untuk

Membentuk Karakter. Jakarta: PT

Bumi Aksara

Maksudin. (2013). Pendidikan Karakter

Non-dikotomik. Yogjakarta: Pustaka

Pelajar

Moleong, Lexy J. (2013). Metodologi

Penelitian Kualitatif. Edisi Revisi.

Bandung: PT Remaja Rosdakarya

Sugiono. (2014). Metode Penelitian

Kuantitatif Kualitatif dan $R \& D$.

Bandung: Alfabeta

Suharsimi Arikunto. (2006). Prosedur

Penelitian: Suatu Pendekatan

Praktik.Edisi Revisi VI. Jakarta: PT

Rineka Cipta

Ridwan, M. (2016). Ajaran moral dan karakter dalam fabel kisah dari negeri dongeng karya mulasih tary (kajian sastra anak sebagai bahan ajar di sekolah dasar). Premiere Educandum: Jurnal Pendidikan Dasar dan Pembelajaran, 6(01), 95-109

Ridwan, M. (2017). Tradisi nyanyian anak terhadap pembentukan karakter anak usia sekolah dasar. Sekolah Dasar: Kajian Teori dan Praktik Pendidikan, 26(1), 49-61.

Ridwan, M. (2018). Learning of local environmental wisdom in oral literature of madurese traditional song in sumenep. ISCE: Journal of
Innovative Studies on Character and Education, 2(1), 93-103

Ridwan, M., \& Ridwan, M. (2016). Pendidikan karakter berbasis permainan tradisional siswa sekolah dasar di sumenep madura. In PROSIDING SEMINAR NASIONAL "Optimalisasi Active Learning dan Character Building dalam Meningkatkan Daya Saing Bangsa di Era Masyarakat Ekonomi Asean (MEA)” (pp. 131-135). Prodi Pendidikan Guru Sekolah Dasar dan Prodi Bimbingan dan Konseling.

Ridwan, M., \& Wahdian, A. (2017). Structure, function and value the tradition of oral literature in sumenep madura. ISLLAC: Journal of Intensive Studies on Language, Literature, Art, and Culture, 1(1), 252-273.

Sukardi. (2003). Metodelogi Penelitian Komptensi dan Praktiknya. Jakarta: Bumi Akasara

Zaim Elmubarok. (2008). Membumikan Pendidikan Nilai. Bandung: Afabeta. 